\title{
INTRAOVARIAN \\ CONTROL MECHANISMS
}




\section{ADVANCES IN EXPERIMENTAL MEDICINE AND BIOLOGY}

Editorial Board:

NATHAN BACK, State University' of New' York at Buffalo

NICHOLAS R. DI LUZIO. Tulane University School of Medicine

EPHRAIM KATCHALSKI-KATZIR, The Weizmann Institute of Science

DAVID KRITCHEVSKY, Wistar Institute

ABEL LAJTHA, Rockland Research Institute

RODOLFO PAOLETTI, University of Milan

Recent Volumes in this Series

Volume 140

COMPOSITION AND FUNCTION OF CELL MEMBRANES: Application

to the Pathophysiology of Muscle Diseases

Edited by Stewart Wolf and Allen K. Murray

Volume 141

BIOCHEMISTRY AND FUNCTION OF PHAGOCYTES

Edited by F. Rossi and P. Patriarca

Volume 142

BIOCHEMISTRY AND BIOLOGY OF CORONAVIRUSES

Edited by V. ter Meulen, S. Siddell, and H. Wege

Volume 143

RELAXIN

Edited by Ralph R. Anderson

Volume 144

MUCUS IN HEALTH AND DISEASE - II

Edited by Eric N. Chantler, James B. Elder, and Max Elstein

Volume 145

TERMINAL TRANSFERASE IN IMMUNOBIOLOGY AND LEUKEMIA

Edited by Umberto Bertazzoni and F. J. Bollum

Volume 146

MECHANISMS OF CELL-MEDIATED CYTOTOXICITY

Edited by William R. Clark and Pierre Golstein

Volume 147

INTRAOVARIAN CONTROL MECHANISMS

Edited by Cornelia P. Channing and Sheldon J. Segal

Volume 148

STRUCTURE AND FUNCTION RELATIONSHIPS IN BIOCHEMICAL SYSTEMS

Edited by Francesco Bossa, Emilia Chiancone, Alessandro Finazzi-Agrò, and Roberto Strom 


\section{INTRAOVARIAN CONTROL MECHANISMS}

Edited by

\section{Cornelia P. Channing}

Department of Physiology

School of Medicine

University of Maryland

Baltimore, Maryland

and

Sheldon J. Segal

Population Division

The Rockefeller Foundation

New York, New York 


\section{Library of Congress Cataloging in Publication Data}

Conference on Intraovarian Control Mechanisms (1981: Bellagio, Italy)

Intraovarian control mechanisms.

(Advances in experimental medicine and biology; v. 147)

Includes bibliographical references and index.

1. Ovaries-Congresses. 2. Hormones, Sex-Physiological effect-Congresses. 3. Cellular control mechanisms - Congresses. I. Channing, Cornelia P. II. Segal, Sheldon Jerome, Date- . III. Title. IV. Series. [DNLM: 1. Ovary-Physiology-Congresses. W1 AD559 v. 147 / WP 320 C747i 1981]

QP261.C67 1981

599.01'6

82-9849

ISBN-13: 978-1-4615-9280-8

e-ISBN-13: 978-1-4615-9278-5

DOI: $10.1007 / 978-1-4615-9278-5$

AACR2

Proceedings of a Conference on Intraovarian Control Mechanisms, held April 28-30, 1981, at the Villa Serbelloni, in Bellagio, Italy

\section{(C) 1982 Plenum Press, New York}

Softcover reprint of the hardcover 1st edition 1982

A Division of Plenum Publishing Corporation 233 Spring Street, New York, N.Y. 10013

\section{All rights reserved}

No part of this book may be reproduced, stored in a retrieval system, or transmitted in any form or by any means, electronic, mechanical, photocopying, microfilming, recording, or otherwise, without written permission from the Publisher 


\section{PREFACE}

Recently intraovarian control of steroidogenesis and oocyte maturation has become a subject of interest. Non steroidal substances secreted locally by the ovarian follicle and corpus luteum have been implicated in control of oocyte maturation follicular maturation and steroldogenesis as well as luteal function. In addition some ovarian polypeptides such as inhibin $F$ (folliculostatin) leave the ovary and act as modulators of pituitary function which in turn regulates ovarian function by exhibiting changes in follicle stimulating hormone secretion in response to changes in inhibin. It was desired to see how these intraovarian regulators act to control ovarian function. In addition it was of interest to see what the chemical nature of these intraovarian regulators is. To achieve these ends a meeting was held at the Villa Serbelloni in Bellagio situated overlooking Lake Como. Leaders in this field were invited and asked to vigorously discuss the subject of intraovarian control mechanisms. Their manuscripts comprise this volume. 
CONTENTS

Maturation, Morphology, and Endocrine Function

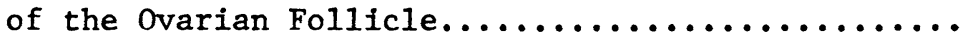

Lars Bjersing

Role of Ovarian Inhibin (Folliculostatin)

in Regulating FSH Secretion in the Female Rat.....

Neena B. Schwartz

Purification, Characterization, and In Vitro

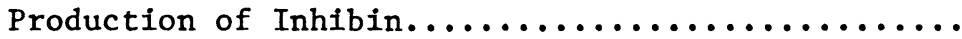

F. H. de Jong, E. H. J. M. Jansen,

W. P. Hermans, and H. J. van der Molen

Hormonal Control of Inhibin Secretion...............

Larry D. Anderson and Dennis J. Hoover

Characteristics of Inhibin:

A Comparative Study Using Bull and Human

Seminal Fluids and Porcine Follicular Fluid.......

M. R. Sairam, K. Kato, P. Manjunath,

K. Ramasharma, W. M. Miller, E. S. R. Haung,

and H. G. MadhwaRaj

Partial Purification of Porcine Follicular

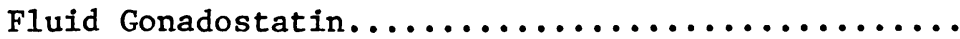

A. T. Williams and H. Lipner

Purification of Gonadostatin from Bovine

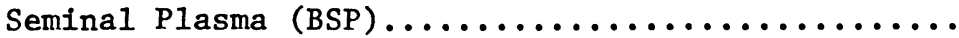

Shao-Yao Ying, Nicholas C. Ling,

Frederick S. Esch, Roger Guillemin,

and Wayne $B$. Watkins 
Properties of Follicle Stimulating Hormone Binding

Inhibitors Found in Physiological Fluids..........

Leo E. Reichert, Jr., Michael A. Sanzo,

Paul W. Fletcher, James A. Dias,

and $C$. Y. Lee

Oocyte Maturation Inhibitor:

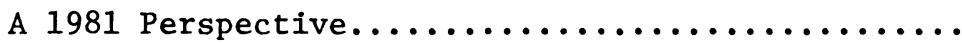

A. Tsafriri and S. Bar-Ami

Meiotic Arresting Substance Separated

from Porcine Ovarian Granulosa Cells

and Hypothetical Arresting Mechanism

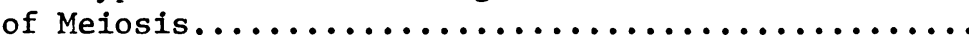

Eimei Sato, Takehiko Ishibashi, and Akira Iritani

Role of Cumulus Cells in Oocyte Maturation.............

Torbjörn Hillensjö, Claes Magnusson,

Carl Ekholm, Hảkan Billig, and Lars Hedin

Actions of Hormones and Other Factors

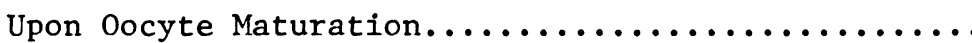

Cornelia P. Channing, Seymour H. Pomerantz,

In-Ha Bae, Valerie W. Evans,

and Susan J. Atlas

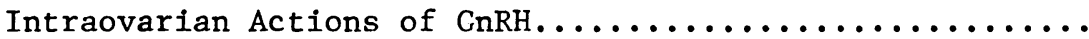

Fernand Labrie, Carl Séguin, Fleur-Ange Lefebvre,

Jocelyne Massicotte, Georges Pelletier,

Jean-Philippe Borgus, Paul-A. Kelly,

Jerry J. Reeves, and Alain Bélanger

Regulation of Ovarian Granulosa and Luteal Cell

Functions by Gonadotropin Releasing

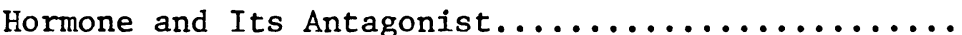

Aaron J. W. Hsueh and Phillip B. C. Jones

LH-Binding Inhibitors from the Corpus Luteum..........

Darrell N. Ward, Wan-Kyng Liu,

Stephan D. Glenn, and Cornelia P. Channing

Characterization of LH/hCG Receptor Binding

Inhibitor in Corpora Lutea of Human

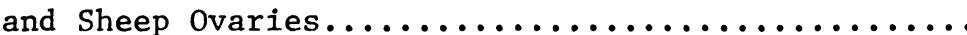

G. L. Kumari, Narender Kumar, S. Duraiswami,

J. K. Datta, I. C. Vidyasagar,

S. Vohra, and S. Roy 
Regulation of Cholesterol Acquisition

and Utilization in the Corpus Luteum.

Jerome F. Strauss, III, Toshinobu Tanaka,

Leslie MacGregor, and Richard W. Tureck

Some Observations that May Pertain

to Structure-Function Relationships of hCGß........

Robert Ryan, Patrick McIlroy,

Kavi Ratanabanangkoon,

and Henry Keutmann

Stimulation of Granulosa Cell Maturation

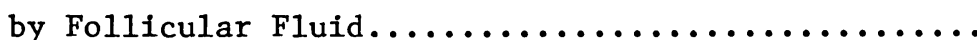

Florence Ledwitz-Rigby, Brian W. Rigby,

Su Yu Ling, Luanne Stewart, and Mark McLean

Intraovarian Regulation of Granulosa-Ce11

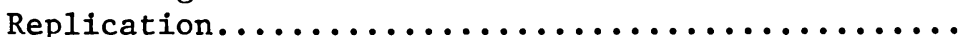

James M. Hammond, Johannes D. Veldhuis,

Thomas W. Seale, and Matthew M. Rechler

Comparison of Granulosa and Sertoli Cells

at Various Stages of Maturation:

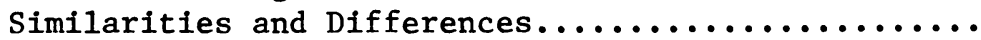

Irving B. Fritz

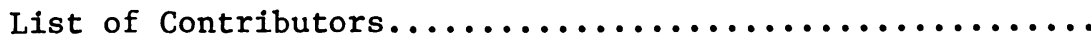

Author Index $\ldots \ldots \ldots \ldots \ldots \ldots \ldots \ldots \ldots \ldots \ldots \ldots \ldots \ldots \ldots \ldots \ldots \ldots$

Subject Index $\ldots \ldots \ldots \ldots \ldots \ldots \ldots \ldots \ldots \ldots \ldots \ldots \ldots \ldots \ldots \ldots \ldots$ 